philus but can be given only parenterally. Erythromycin, rifampicin, and lincomycin do not appear suitable for treating haemophilus infections and the value of clindamycin remains in doubt.

\section{References}

Ayliffe, G. A. J., and Pride, N. B. (1962). British Medical fournal, 2, 1641 Bell, S. M. (1971). Medical fournal of Australia, 2, 1280.

Braun, P., Tillotson, J. R., Wilcox, C., and Finland, M. (1968). fournal of Applied Microbiology, 16, 1684

Citron, K. M., and May, J. R. (1969). Lancet, 2, 982.

Darrell, J., Garrod, L. P., and Waterworth, P. M. (1969). fournal of Clinical Pathology, 21, 202.

Garrod, L. P., and O'Grady, F. W. (1972). Antibiotic and Chemotherapy. London, Churchill Livingstone.

Griffith, R. S., and Black, H. R. (1964). American fournal of the Medical Sciences, 247, 69.

Griffith, R. S., and Black, H. R. (1970). Medical Clinics of North America, $54,1229$.

Howard, P. (1967). British Medical fournal, 1, 573.

Hughes, D. T. D. (1969). British Medical fournal, 4, 470
Kosmidis, J., Williams, J. D., Andrews, J., Goodall, J., and Geddes, A. M. (1972). British fournal of Clinical Practice, 26, 7 .

Kucers, A. (1972). Use of Antibiotics. London, Heinemann.

Malone, D. N., Gould, J. C., and Grant, I. W. B. (1968). Lancet, 2, 594.

Mathies, A. W., et al. (1966). Antimicrobial Agents and Chemotherapy, 5, 610

May, J. R. (1968). Chemotherapy of Chronic Bronchitis and Allied Disorders, p. 26. London, English University Press.

p. 26. London, English University Press.
May, J. R., and Davies, J. (1972). British Medical fournal, 3, 376.

May, J. R., and Ingold, A. (1972). British fournal of Diseases of the Chest, 66,

Pines, A., Greenfield, J. S. B., Raafat, H., Rahman, M., and Siddiqui, A. M. (1969). Postgraduate Medical fournal, 45, Nov. Suppl., p. 89. Phillips, I., Fernandes, R., and Warren, C. (1970). British Medical fournal,

Prescott, L. F., and Nimmo, J. (1970). Acta Pharmacologica et Toxicologica, 29, Suppl. No. 3, p. 288 .

Reeves, D. S. (1971). Fournal of Clinical Pathology, 24, 430.

Rolinson, G. N., and Stevens, S. (1961). British Medical fournal, 2, 191.

Ryden, R. (1973). Personal communication.

Stewart, G. T., Coles, H. M. T., Nixon, H. H., and Holt, R. J. (1961). British Medical fournal, 2,200 .

Sutherland, R., Croydon, E. A. P., and Rolinson, G. N. (1972). British Medical fournal, 3,13 .

Taylor, J. C., and Fallon, R. J. (1966). Lancet, 1, 715.

Walker, A. N., Bailey, A., Hart, S., Hadley, A., and James, D. G. (1970). Postgraduate Medical Fournal, 46, Oct. Suppl., p. 146.

Williams, J. D., and Geddes, A. M. (1973). British Medical fournal, 2, 613. Zinnemann, K., and Frazer, J. (1970). British Medical fournal, 2, 481.

\title{
Progesterone Deficiency and Premature Labour
}

\author{
A. I. CSAPO, O. POHANKA, H. L. KAIHOLA
}

British Medical fournal, 1974, 1, 137-140

\section{Summary}

Plasma oestradiol $17 \beta$ and progesterone levels in 11 patients admitted to hospital for threatened premature labour of unknown aetiology were compared with those of women at similar stages of gestation whose pregnancy was normal. Oestradiol levels in the study group were slightly higher than in the normal controls but their progesterone levels were significantly lower. This progesterone deficiency increased the oestradiol/progesterone ratio in the study group patients, and it increased still more as the progesterone withdrawal continued during premature labour.

Since uterine activity during pregnancy is regulated by a balanced action of several factors a deficiency in progesterone, an opponent of uterine activity, creates a regulatory imbalance which, if uncorrected, provokes premature labour. An increase in uterine volume stimulates uterine activity, and the present study reinforced our previous conclusion that the uterine-volume/plasma-progesterone ratio is a more accurate measure of the state of regulatory balance than the progesterone level alone.

The cause of the progesterone deficiency in these cases remains unexplained, but we suggest that placental growth and function are contributory factors. We are investigating ways of correcting the resulting imbalance in the regulatory mechanism.

$\overline{\text { Department of Obstetrics and Gynaecology, Washington University }}$ A. I. CSAPO, M.D., Professor

Department of Obstetrics and Gynaecology, Debrecen University, Hungary

O. POHANKA, M.D., Assistant Professor

Department of Obstetrics and Gynaecology, Turku University, Finland

H. L. KAIHOLA, m.sc, Research Associate

\section{Introduction}

Agreement is still lacking on the exact nature of the physiological processes that control the onset of labour. A uterine stimulatory mechanism is known to build up during pregnancy (Csapo, 1969), and prostaglandin has been identified as the intrinsic myometrial stimulant. Synthesis of prostaglandin is promoted by the increase in uterine volume (Csapo, 1972) and by oestradiol (Caldwell et al., 1972), and the action of the intrinsic stimulatory mechanism is amplified by oxytocin and by fetal factors (Perry, 1972). That pregnancy is normally maintained despite this stimulus to uterine activity may be explained if the gestational rise in progesterone output is regarded as a fetoplacental effort to counterbalance the action of the stimulatory mechanism, and the terminal fall in progesterone as the end of that effort. Thus pregnancy is maintained by a regulatory balance of opposing forces. If that is so then, provided the potential of the stimulatory mechanism is undiminished, progesterone withdrawal during pregnancy should provoke premature labour. The present study aimed to test this theory and also to re-examine the contention (Csapo et al., 1970) that the uterine-volume/plasmaprogestenone ratio is the controlling factor in myometrial activity and that this ratio is a more accurate indicator of the state of uterine regulatory balance than the plasma progesterone level alone.

\section{Patients and Methods}

A study group was chosen consisting of 11 patients admitted to hospital because of threatened premature labour. Their average age was 23 years and their average stage of gestation 34 weeks (table I). Criteria for admission to the study were : (1) the presence of uterine activity and more effacement and dilatation of the cervix than expected at 30 to 36 weeks' pregnancy and more than observed at previous examinations; (2) the absence of any clear clinical cause of premature labour, such as hydramnois, fetal death, twin pregnancy, or incom- 
petent cervix; and (3) that no previous treatment had been given to suppress uterine activity which might interfere with the study.

TABLE I-Obstetric Details of 11 Study Group Patients

\begin{tabular}{|c|c|c|c|c|c|}
\hline \multirow{2}{*}{ Case No. } & \multirow{2}{*}{$\begin{array}{c}\text { Age } \\
\text { (Years) }\end{array}$} & \multirow[t]{2}{*}{ Cravida } & \multirow{2}{*}{ Para } & \multicolumn{2}{|c|}{ Gestational Age (Weeks) } \\
\hline & & & & On Admission & At Delivery \\
\hline $\begin{array}{r}1 \\
2 \\
3 \\
4 \\
5 \\
6 \\
7 \\
8 \\
9 \\
10 \\
11\end{array}$ & $\begin{array}{l}20 \\
27 \\
28 \\
25 \\
25 \\
24 \\
20 \\
17 \\
20 \\
20 \\
25\end{array}$ & $\begin{array}{l}1 \\
2 \\
2 \\
5 \\
3 \\
2 \\
1 \\
1 \\
1 \\
3 \\
3\end{array}$ & $\begin{array}{l}1 \\
1 \\
2 \\
2 \\
2 \\
2 \\
1 \\
1 \\
1 \\
1 \\
2\end{array}$ & $\begin{array}{l}35 \\
35 \\
32 \\
32 \\
30 \\
35 \\
30 \\
32 \\
36 \\
36 \\
36\end{array}$ & $\begin{array}{l}35 \\
36 \\
36 \\
32 \\
31 \\
36 \\
30 \\
32 \\
36 \\
37 \\
37\end{array}$ \\
\hline $\begin{array}{l}\text { Mean }( \pm \text { S.E. } \\
\text { of Mean) }\end{array}$ & $23 \pm 1$ & $2 \pm 1$ & $1 \pm 1$ & $34 \pm 1$ & $35 \pm 1$ \\
\hline
\end{tabular}

In three of the patients uterine contractions strengthened and they were delivered within about six hours. The remaining eight patients went into labour and were delivered after varying periods of rest in bed (table I). One patient was delivered by caesarean section because of prolapse of the cord.

In addition to day-to-day clinical management serial estimations of plasma progesterone and plasma oestradiol $17 \beta$ concentrations were made by radioimmunoassay (Csapo et al., 1972 a). Normal values for comparison were available from earlier estimations of plasma progesterone and oestradiol $17 \beta$ levels in 12 patients at a similar stage of pregnancy as the study group patients but under hospital obstetric care for social reasons (Csapo et al., 1971; Kaihola et al., 1973).

\section{Results}

The 11 babies of the mothers in the study group were all born alive. Four, however, died after periods of up to 30 hours of intensive care. The average weight of the infants ( \pm S.E. of mean) was $2,123 \pm 165 \mathrm{~g}$ and their crown to heel measurement $45 \pm 1 \mathrm{~cm}$ (table II), which agreed with their calculated gestational age. In only three cases was the birth weight in excess of $2,500 \mathrm{~g}$. The average placental weight was $347 \pm 23 \mathrm{~g}$, which is less than the normal (425 g) at $35 \pm 1$ weeks of pregnancy (Eastman and Hellman, 1966). If weight is an index of the steroidogenic potential of the placenta these placentas were inadequate for maintaining pregnancy.

The plasma oestradiol $17 \beta$ (fig. 1) and plasma progesterone (fig. 2) levels were based on repeated analyses of a total of 37 samples of plasma from the study group of 11 patients and of a total of 92 samples from the 12 normal control patients. Pregnancy in all the control patients had gone to term (275 \pm 3 days) and they all spontaneously delivered mature infants (average birth weight $3,169 \pm 97 \mathrm{~g}$ ).

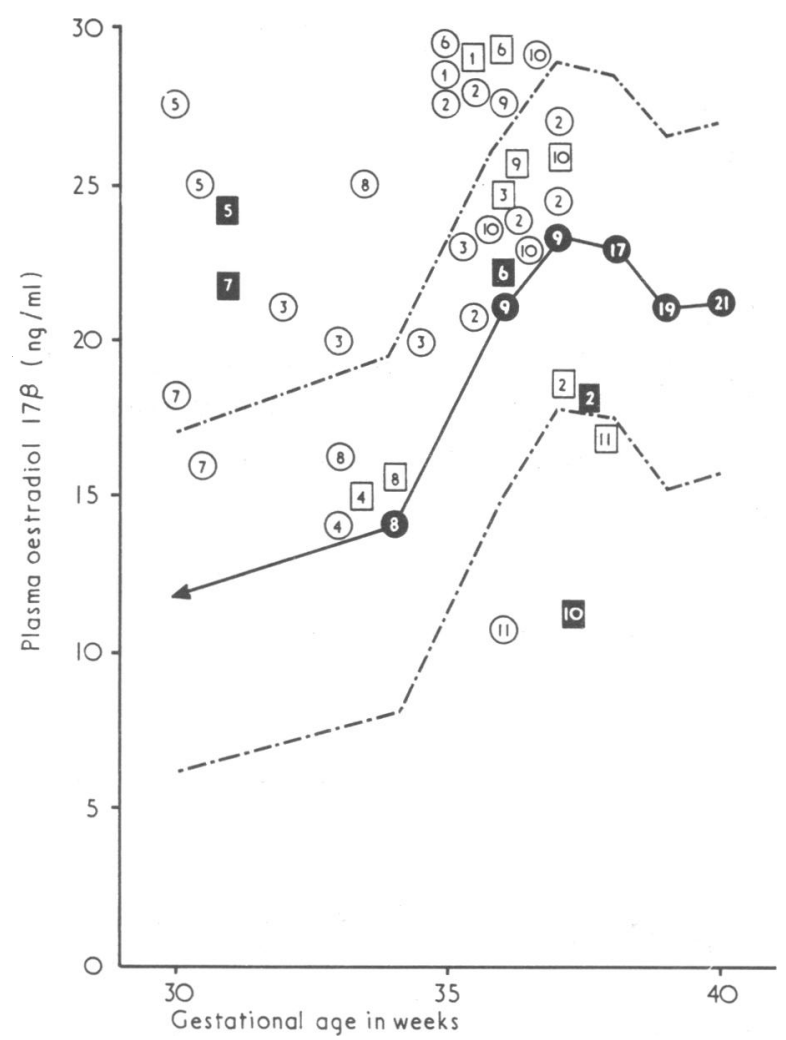

FIG. 1-Plasma oestradiol levels in the study group patients and normal controls. $=$ Mean of levels in controls (numbers indicate number of plasmas assayed). $O=$ Individual levels in study group patients under observation for threatened premature labour (numbers are case Nos.). $\square=$ Individual levels in patients in premature labour (numbers are case Nos.). $\mathbf{0}=$ Individual levels in patients at premature delivery (numbers are case Nos.). -....... = Average standard deviations from mean in controls.

Plasma oestradiol $17 \beta$ levels (fig. 1) continued to rise in the normal control patients until the 37th week of gestation, when a plateau was reached (Rado et al., 1970; Csapo et al., 1971). Levels of oestradiol $17 \beta$ in 26 samples of plasma taken from normal controls at about the 35 th week of gestation averaged $20 \pm 1 \mathrm{ng} / \mathrm{ml}$. The oestradiol $17 \beta$ levels in 19 samples of plasma from the study group patients at the 35th week averaged $26 \pm 2 \mathrm{ng} / \mathrm{ml}-$ slightly higher than in the controls (P $<0.05$ ). There was no statistically significant fall in oestradiol levels during labour in either the control or study group of patients. Uterine activity therefore did not seem significantly to affect the oestradiologenic potential of the fetoplacental unit.

Plasma progesterone levels (fig. 2) in the control patients fell significantly from $173 \pm 6 \mathrm{ng} / \mathrm{ml}$ at the 37th week of gestation to $141 \pm 6 \mathrm{ng} / \mathrm{ml}(\mathrm{P}<0.001)$ during labour (Csapo et al., 1971). The average progesterone level in 26 plasma

TABLE II-Statistics of Premature Labours in 11 Study Group Patients

\begin{tabular}{|c|c|c|c|c|c|c|c|}
\hline \multirow{2}{*}{ Case No. } & \multicolumn{2}{|c|}{ State of Cervix on Admission } & \multirow{2}{*}{$\begin{array}{l}\text { Uterine } \\
\text { Activity } \\
\text { on } \\
\text { Admission }\end{array}$} & \multicolumn{2}{|c|}{ Fetal Size } & \multirow{2}{*}{$\begin{array}{c}\text { Placental } \\
\text { Weight } \\
\text { (g) }\end{array}$} & \multirow{2}{*}{$\begin{array}{c}\text { Duration } \\
\text { of } \\
\text { Labour } \\
\text { (Hours) }\end{array}$} \\
\hline & $\begin{array}{c}\text { Effacement } \\
\left(\begin{array}{c}0 \\
0\end{array}\right)\end{array}$ & $\begin{array}{c}\text { Dilatation } \\
(\mathrm{cm})\end{array}$ & & $\begin{array}{l}\text { Weight } \\
(\mathrm{g})\end{array}$ & $\begin{array}{l}\text { Length } \\
\text { (cm) }\end{array}$ & & \\
\hline $\begin{array}{r}1 \\
2 \\
3 \\
4 \\
5 \\
6 \\
7 \\
8 \\
9 \\
10 \\
11\end{array}$ & $\begin{array}{r}70 \\
70 \\
50 \\
100 \\
70 \\
50 \\
80 \\
70 \\
100 \\
20 \\
20\end{array}$ & $\begin{array}{l}2 \\
2 \\
2 \\
4 \\
3 \\
2 \\
2 \\
3 \\
4 \\
2 \\
2\end{array}$ & $\begin{array}{l}++ \\
++ \\
++ \\
+++ \\
++ \\
++ \\
++++ \\
+++ \\
++++ \\
++ \\
++\end{array}$ & $\begin{array}{l}2,300 \\
2,700 \\
2,350 \\
2,000 \\
1,250 \\
2,850 \\
1,850 \\
1,500 \\
1,900 \\
1,950 \\
1,700\end{array}$ & $\begin{array}{l}46 \\
48 \\
48 \\
43 \\
38 \\
48 \\
42 \\
43 \\
50 \\
43 \\
42\end{array}$ & $\begin{array}{l}300 \\
250 \\
300 \\
300 \\
350 \\
510 \\
320 \\
400 \\
430 \\
360 \\
300\end{array}$ & $\begin{array}{c}6 \\
6 \\
5 \\
6 \\
2 \\
8 \\
3 \\
\text { C.S.* } \\
2 \\
14 \\
1\end{array}$ \\
\hline Mean ( \pm S.E. of Mean) & $64 \pm 8$ & $3 \pm 1$ & $3 \pm 1$ & $2,123 \pm 163$ & $45 \pm 1$ & $347 \pm 23$ & $5 \pm 1$ \\
\hline
\end{tabular}

*C.S. = Caesarean section. 
samples from control patients at about the 35th week of gestation was $159 \pm 7 \mathrm{ng} / \mathrm{ml}$. In 19 plasma samples from the study group patients at the 35th week of gestation and before the start of premature labour the average progesterone level was $100 \pm 8 \mathrm{ng} / \mathrm{ml}$-very significantly lower than the level in the control patients $(P<0.001)$. Even lower was the average progesterone level of $71 \pm 6 \mathrm{ng} /$ $\mathrm{ml}$ in 18 plasma samples from the study group patients during premature labour. In contrast to the oestradiol $17 \beta$ level the plasma progesterone level fell significantly both during premature labour in the study group patients and during labour at term in the control patients.

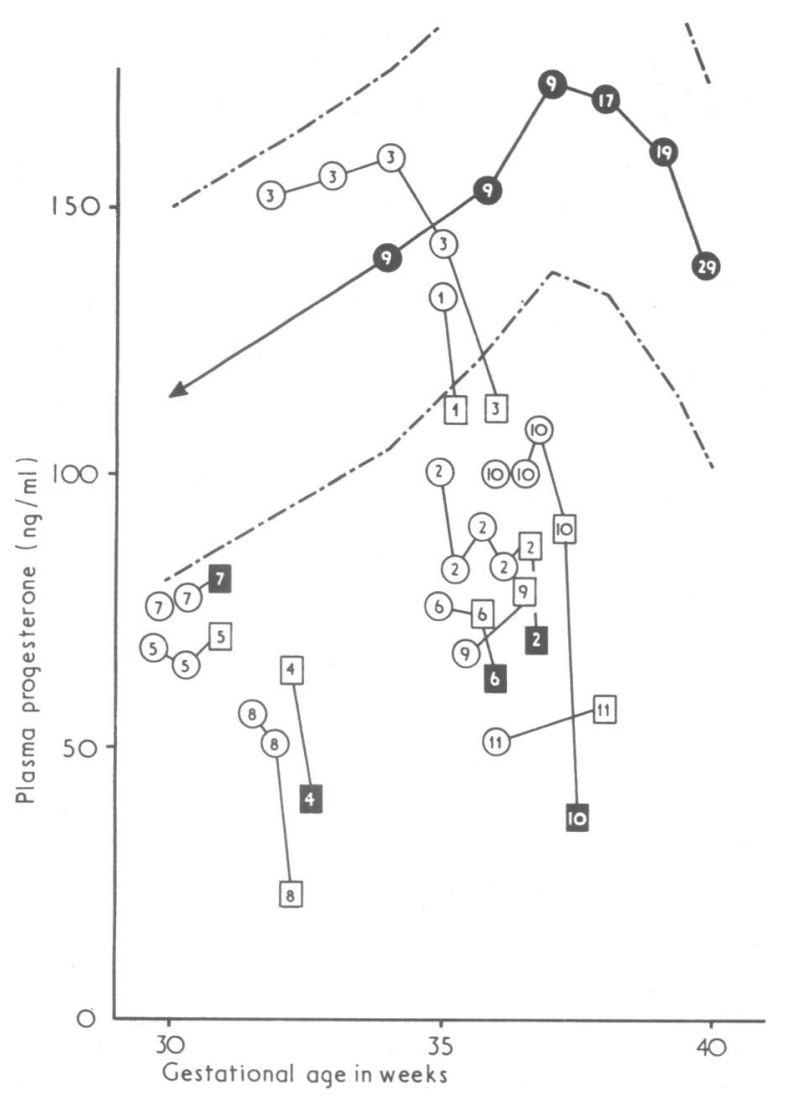

FIG. 2-Plasma progesterone levels in the study group patients and normal controls. $=$ Mean of levels in controls (numbers indicate number of plasmas assayed). $O=$ Individual levels in study group patients under observation for threatened premature labour (numbers are case Nos.) $\square=$ Individual levels in patients in premature labour (numbers are case Nos.). $\square=$ Individual levels in patients at premature delivery (numbers ar
case Nos.).......$=$ Average standard deviations from mean in controls.

Thus comparison of the pregnancy steroid profile of the 11 study group patients with that of the 12 normal control patients shows a regulatory imbalance in the study group charaoterized by a progesterone deficiency and an increase in the oestradiol/progesterone ratio. Since the progesterone level continued to fall during premature labour in the study group patients their oestradiol/progesterone ratio increased still further compared with the control patients.

The contention (Csapo et al., 1970) that myometrial activity is controlled (other factors being constant) by the uterinevolume/plasma-progesterone ratio and therefore, as uterine volume increases with gestational age, this ratio is a better indicator of the state of the regulatory balance than the progesterone level alone was re-examined by relating the birth weights of the premature babies to the plasma progesterone levels of the study group patients. Six mothers had babies weighing $2,000 \mathrm{~g}$ or less (mean $1,708 \pm 118 \mathrm{~g}$ ) and five had babies weighing more than $2,000 \mathrm{~g}$ (mean $2,620 \pm 125 \mathrm{~g}$ ) ( $\mathrm{P}$ $<0.001)$. The six mothers with the smaller babies had a mean progesterone level of $52 \pm 9 \mathrm{ng} / \mathrm{ml}$ during labour, while in the other five it was $90 \pm 12 \mathrm{ng} / \mathrm{ml}(\mathrm{P}<0.05)$. Thus premature labour in these two groups of mothers was associated with dissimilar progesterone levels but similar uterinevolume/plasma-progesterone ratios, if the size of the fetus is taken as the major contributor to uterine volume.

\section{Discussion}

The oestradiol/progesterone ratio was initially higher in the study group patients than in the controls, and as premature labour progressed in the studv patients the ratio increased still further because progesterone levels fell. It might be argued that this was a conseauence rather than a cause of the premature uterine activity, since some uterine activity was already present on admission to hospital. The same argument has been advanced in debates on the sienificance of a fall in progesterone levels preceding successful induced abortions (Csapo et al., 1970; Csapo, 1972) and induced labours (Csapo et al., 1971). By reducing uterine blood flow increased uterine activity might affect placental endocrine funotion, but since in the third trimester both oestradiol and progesterone are of placental origin it is difficult to see how uterine activity could affect the placental production of one and not the other. Also in eight of the 11 study group patients premature labour did not occur until a week after admission, so uterine activity in their case was not great at first. Furthermore, they already showed a plasma progesterone deficiency on admission. Failure in placental growth and function, reflected in subnormal placental weight, seems more plausible than increase in uterine activity as the reason for the progesterone deficiency in the study group patients.

If progesterone deficiency was the cause of premature labour how did it provoke the necessary uterine activity? Only the intrinsic mvometrial stimulants can do that (Csapo, 1969; Csapo, 1972). Progesterone deficiency, however, can promote intrinsic mvometrial stimulation by lowering threshold (Csapo, 1969). An increase in uterine volume promotes uterine activity in both pregnant and non-pregnant women (Csapo, 1969; Csapo et al., 1970; Csapo, 1971; Pulkkinen et al., 1973). Furthermore, when progesterone levels are low even a small increase in uterine volume can provoke abortion (Csapo et al., 1963). These findings together with the results of animal experiments lead to the conclusion (Csapo, 1969; Csapo et al., 1970; Csapo, 1971) that the uterine-volume/ plasma-progesterone ratio is a more accurate measure of the regulatory balance of the uterus than the plasma progesterone level alone.

It has recently been shown (Csapo, 1971; Poyser et al., 1971; Csapo, 1972) that stretching the mvometrium promotes synthesis of prostaglandin and increases uterine activity, while relaxing it has the opposite effect. Apparently the intrinsic myometrial stimulant is prostaglandin, and the increase in uterine volume and in oestradiol during normal pregnancy sustains an effective stimulatory mechanism by promoting prostaglandin svnthesis (Poyser et al., 1971; Caldwell et al., 1972; Csapo, 1972).

The concept that a proper balance between prostaglandin and progesterone levels is required to maintain pregnancy and that an increase in the prostaglandin/progesterone ratio provokes labour has been substantiated by the finding (Csapo et al., 1972 b; Csapo et al., 1973 a) that a withdrawal of progesterone induced by luteectomy early in the first trimester of pregnancy leads to abrrtion without any other supportive measure. Patients luteectomized late in the first trimester, however, did not abort, presumably because the shift in progesterone production from corpus luteum to placenta was by then enough to prevent continual progesterone withdrawal. Also 
abortion was prevented by progesterone substitution in women luteectomized early in the first trimester. Therefore it seems that the degree of progesterone deficiency found in the patients in the present study could have upset the regulatory balance enough to provoke precocious uterine activity and premature labour.

In this context the case of another patient, excluded from the study because the criteria for entry were not satisfied, is of interest. She was admitted at 30 weeks' gestation with no symptoms of threatened premature labour but because of cervical dilatation and effacement due to incompetence of the cervix. Despite this, subsequent rupture of the membranes, and a small fetus $(1,900 \mathrm{~g})$ premature labour did not begin until induced by oxytocin. The oestradiol level at 30 weeks was normal $(12 \mathrm{ng} / \mathrm{ml})$ but the progesterone level (200 $\mathrm{ng} /$ $\mathrm{ml}$ ) exceeded the normal control value $(159 \mathrm{ng} / \mathrm{ml})$. The placenta $(500 \mathrm{~g})$ also exceeded the normal weight (425 g). Apparently in this patient pregnancy was maintained by a decreased oestradiol/progesterone ratio.

Though the causes of the progesterone deficiency and the increased oestradiol/progesterone ratio in the study group of patients remains unexplained, the recognition that this regulatory imbalance characterizes some types of threatened pregnancies is a step towards understanding the aetiology of premature labour and thus its prevention. Since there are inherent difficulties in correcting progesterone deficiency therapeutically when the placenta is the site of progesteronegenesis, stimulation of placental growth and function seems an appropriate measure. This possibility is now being explored (Csapo, 1971). Another rational course would be to restore the prostaglandin/progesterone balance by suppressing prostaglandin synthesis. Some success in this direction has already been achieved (Csapo et al., 1973 b).
This study was supported by the Agency for International Developmen+, Department of State, contract No. AID/csd 3160; by the Population Council, subcontract 006, AID/csd 2491; by the National Institutes of Health, contract No. 69-2194; and by the National Institutes of Health Career Award HD 20169-10.

\section{References}

Caldwell, B. V., Tillson, S. A., Brock, W. A., and Speroff, L. (1972) Prostaglandins, 1, 217

Csapo, A. I. (1969). In Ciba Foundation Study Group No. 34, Progesterone: Its Regulatory Effect on the Myometrium, ed. G. E.W. Wolstenholme and J. Knight. Londor, Churchill.

Csapo, A. I. (1971). In Contractile Proteins and Muscle, ed. K. Laki, p. 413 New York, Dekker.

Csapo, A. I. (1972). Fournal of Reproductive Medicine, 9, 400

Csapo, A. I., Jaffin, H., Kerenyi, T., De Mattos, C. E. R., and Sousa-Filho, M. B. (1963). American fournal of Obstetrics and Gynecology, 87, 892 Csapo, A. I., Sauvage, J. P., and Wiest, W. G. (1970). American fournal of Obstetrics and Gynecology, 108, 950

Csapo, A. I., Knobil, E., Van Der Molen, H. J., and Wiest, W. G. (1971). American fournal of Obstetrics and Gynecology, 110, 630.

Csapo, A. I., Kivikoski, A., and Wiest, W. G. (1972 a). Prostaglandins, 2, 125.

Csapo, A. I. Pulkkinen, M. O., Ruttner, B., Sauvage, J. P., and Wiest, W. G. (1972 b). American fournal of Obstetrics and Gynecology, 112,

Csapo, A. I., Pulkkinen, M. O., and Wiest, W. G. (1973 a). American fournal of Obstetrics and Gynecology, 115, 759 .

Csapo, A. I., Csapo, E. F., Fay, E., Henzl, M., and Salau, G. (1973 b) Prostaglandins. In press.

Eastman, N. J., and Hellman, L. M. (editors) (1966). In Williams Obstetrics, 13 th edn. New York, Meredith.

Kaihola, H. L., Wiest, W. G., and Csapo, A. I. (1973). Unpublished observations.

Perry, J. S. (1972). Journal of Reproduction and Fertility, Suppl. No. 16.

Poyser, N. L., Horton, E. W., Thompson, C. J., and Los, M. (1971). Nature, 230, 526.

Pulkkinen, M. O., Liukko, P., Piiroinen, O., and Rauramo, L. (1973). Acta Obstetricia et Gynecologica Scandinavica, 52, 9.

Rado, A., Crystle, C. D., and Townsley, J. D. (1970). Journal of Clinical Endocrinology, 30, 497.

\title{
The Mallory-Weiss Syndrome
}

\author{
D. J. B. ST. JOHN, J. P. MASTERTON, N. D. YEOMANS, H. A. F. DUDLEY
}

British Medical fournal, 1974, 1, 140-143

\section{Summary}

A policy of immediate investigation of patients with haematemesis or melaena or both led to the diagnosis of the Mallory-Weiss syndrome in 16 out of 121 patients admitted to a combined medical-surgical unit over three and a half years. A typical history suggestive of the diagnosis was obtainable in only nine of the 16 patients, though recent alcohol intake was high in another four. All patients survived the episode. Establishment of the diagnosis by oesophagogastroscopy was of special benefit when surgery was needed for control of continuing blood loss, but it also simplified the subsequent medical man-

Monash University Medical School, Alfred Hospital, Melbourne 3181, Australia

D. J. B. ST. JOHN, F.R.A.C.P., M.R.C.P., Senior Lecturer, Department of

P. MASTERTON, F.R.C.s., F.R.A.C.s., Associate Professor, Department of N. D. YEOMANS, M.R.A.C.P., Research Fellow, Department of Medicine (Present address: Anatomy Department C, University of Copenhagen, Copenhagen)

H. A. F. DUDLEY, CH.M., F.R.C.S., Chairman and Professor, Department of Surgery (Present address : Surgical Unit, St. Mary's Hospital, London of Surgery agement of those patients in whom bleeding stopped spontaneously. The incidence of $13.2 \%$ in this series suggests that the Mallory-Weiss syndrome may be a relatively common cause of upper gastrointestinal bleeding.

\section{Introduction}

For the three decades after its original description (Mallory and Weiss, 1929) the Mallory-Weiss syndrome was thought to be a rare cause of upper gastrointestinal bleeding. More recently, however, reports of cases have raised the possibility that the syndrome might not be so uncommon (Atkinson et al., 1961; Dobbins, 1963; Freeark et al., 1964; Dagradi et al., 1966; Homes, 1966), and in series where early endoscopy has been used routinely in the investigation of haematemesis and melaena the incidence has been found to be $2.0 \%$ (Katz et al., 1965), $2.7 \%$ (Jones, 1969), 5.1\% (Palmer, 1970), and $4.7 \%$ (Pitcher, 1972). An incidence of $14.7 \%$ was reported in the United States army and veteran patients (Wells, 1967), but there was an unduly high proportion of alcoholics in this group. In these series endoscopy was performed either exclusively or, for the most part, with rigid and semi-rigid instruments. The recent introduction of fibreoptic instruments has greatly improved the ease and accuracy of endoscopic examination of the upper gastrointestinal tract. In our medical and surgical unit a policy of 